\title{
A New Perspective of Pseudomonas-Host Interactions: Distribution and Potential Ecological Functions of the Genus Pseudomonas within the Bark Beetle Holobiont
}

\author{
Zaki Saati-Santamaría ${ }^{1,2, *(\mathbb{D})}$, Raúl Rivas ${ }^{1,2,3}$ (D), Miroslav Kolařik ${ }^{4,5}$ (D) and Paula García-Fraile $1,2,3, *(\mathbb{D})$ \\ 1 Microbiology and Genetics Department, University of Salamanca, 37007 Salamanca, Spain; raulrg@usal.es \\ 2 Spanish-Portuguese Institute for Agricultural Research (CIALE), Villamayor, 37185 Salamanca, Spain \\ 3 Associated Research Unit of Plant-Microorganism Interaction, USAL-CSIC (IRNASA), \\ 37008 Salamanca, Spain \\ 4 Department of Botany, Faculty of Science, Charles University, 12801 Prague, Czech Republic; \\ mkolarik@biomed.cas.cz \\ 5 Institute of Microbiology of the Czech Academy of Sciences, Vídeňská 1083, 14220 Prague, Czech Republic \\ * Correspondence: zakisaati@usal.es (Z.S.-S.); paulagf81@usal.es (P.G.-F.)
}

check for updates

Citation: Saati-Santamaría, Z.; Rivas, R.; Kolařik, M.; García-Fraile, P. A New Perspective of Pseudomonas-Host Interactions: Distribution and Potential Ecological Functions of the Genus Pseudomonas within the Bark Beetle Holobiont. Biology 2021, 10, 164. https:// doi.org/10.3390/biology10020164

Academic Editor: Maria Amélia Martins-Loução

Received: 26 January 2021

Accepted: 16 February 2021

Published: 19 February 2021

Publisher's Note: MDPI stays neutral with regard to jurisdictional claims in published maps and institutional affiliations.

Copyright: (c) 2021 by the authors. Licensee MDPI, Basel, Switzerland. This article is an open access article distributed under the terms and conditions of the Creative Commons Attribution (CC BY) license (https:// creativecommons.org/licenses/by/ $4.0 /)$.
Simple Summary: Microbes play essential roles in the health of animals and plants. Hence, the study of microbe-host interactions is of utmost importance to understand nature. In the present work, we aimed to understand the ecological distribution and functions of the bacterial genus Pseudomonas in bark beetles. These beetles are small insects that live under the bark of trees. Some bark beetle species cause mass attacks in woodlands, decimating tree populations worldwide. Thus, a better understanding of its associated microbes may aid in finding solutions for these forest pests. Our revision summarizes how members of the genus Pseudomonas are ubiquitous in all life stages of different bark beetle species. Moreover, we found that these bacteria may benefit these insects by providing them with nutrients, protecting them from tree chemical defenses and antagonizing entomopathogenic fungi.

Abstract: Symbiosis between microbes and insects has been raised as a promising area for understanding biological implications of microbe-host interactions. Among them, the association between fungi and bark beetles has been generally recognized as essential for the bark beetle ecology. However, many works investigating bark beetle bacterial communities and their functions usually meet in a common finding: Pseudomonas is a broadly represented genus within this holobiont and it may provide beneficial roles to its host. Thus, we aimed to review available research on this microbe-host interaction and point out the probable relevance of Pseudomonas strains for these insects, in order to guide future research toward a deeper analysis of the importance of these bacteria for the beetle's life cycle.

Keywords: host-microbe interaction; forest pests; microbiota; Dendroctonus; insects microbiome; insect-microbe interactions; fungal antagonism; biocontrol; Scolytinae; symbionts

\section{Introduction}

Nature is maintained in a delicate balance, which is currently being greatly affected by the effects of climate change. Consequently, ecosystems are being reshaped, where some species are becoming extinct and others are invading new ecological niches and becoming pests [1]. Among these pests, bark beetles (Coleoptera: Curculionidae: Scolytinae) are responsible for significant damage to forests [2]. In general, these insects spend most of their lives-from egg to adult stages-under the bark of trees, only to emerge in search of new host plants during the reproductive stage, starting a new life cycle [3]. Ecologically, they fall into two separate groups: the wood boring ambrosia beetles, nutritionally dependent on cultivated ambrosia fungi and the phloem-feeding species, which feed mostly on nutrient-rich-bark and phloem [4]. These species of phloeophagous beetles feed on 
a narrow repertoire of tree species, usually involving one single genus [5]. In contrast, ambrosia beetles are broad generalists, attacking unrelated plant genera, and feed on a narrow set of associated ambrosia fungi. In addition, some beetles attack dead trees and others can cause severe damage to trees when high population levels are reached under certain environmental conditions [2].

The same as humans do, bark beetles contain their own microbiome. As found in other insects that interact with plant insects (for a revision see [6-8]), microbial associates cohabit within bark beetles, constituting an entity known as the "bark beetle holobiont" [9]. It has been reported how several of these microbes play an important role in the nutrition of their host [9-11], while some others are able to detoxify the environment, protecting the beetle from tree defense compounds [12] and many of them are known to protect the holobiont from pathogenic microbes [13].

The most conspicuous and well-studied forms of symbiosis between bark beetles and microbes are those established with externally living fungi such as ambrosia and ophiostomatoid species [4]. In contrast to ectosymbionts, little is known about the endosymbionts living in gut or hemolymph. Moreover, although several studies have focused on unveiling the paradigms of the fungus-beetle interaction over the decades $[10,14]$, the bacteria-beetle interactions have only recently received increased attention [9].

A revision of the available literature describing bark beetles' bacterial associates shows a wide distribution of bacteria belonging to the genus Pseudomonas (see next sections). Pseudomonas is a bacterial genus with great metabolic versatility, inhabiting many different environments and hosts [15-18]. Pseudomonas has evolved toward specific beneficial or pathogenic interactions, mainly with plants [19,20], humans [21], and insects [22-24].

Based on the increasing available literature involving bark beetle-bacterial interactions and the relatively large number of reports that identified Pseudomonas as part of the bacteriome of several bark beetles or proposed a relevant role of strains from this genus for their host, this review aims to provide an overview of the state-of-the-art in the association between Pseudomonas and bark beetles, reviewing the potential ecological roles of the microbe within the bark beetle holobiont. We also aim to highlight the existing gaps in the knowledge of this association, providing some clues to test unproven hypotheses on the reported functions of pseudomonads within their host. Finally, considering the worldwide impact of some bark beetle species as forest pests and the capability of some Pseudomonas species to act as insect pathogens, we conclude the review with a section in which the existing knowledge on the use of insect pathogens belonging to Pseudomonas species as biocontrol agents is also presented.

\section{Pseudomonas Bacteria Are Broadly Associated to Bark Beetles}

The bacteriome of the bark beetle holobiont has been characterized in many different culture-dependent studies. Diverse approaches have been developed to obtain bacterial isolates from different body-parts of the beetle such as oral secretions [25], gut [26], cuticle [27], frass [28], or even from the whole crushed insects [29]. In addition, some studies have isolated bacterial strains from the tree galleries where beetles feed [12,30]. Worldwide studies have been also performed to find constant associations in ambrosia beetles [31,32]. The most complex approach includes data from insect bodies of various life stages as well as analysis of the gallery content [33]. The revision of these and other studies points at a bacterial genus very frequently associated with bark beetles: the genus Pseudomonas (Table 1). 
Table 1. Summary of research studies in which Pseudomonas have been found in bark beetles including the host tree of the beetle, the sample type or body part of the beetle from where Pseudomonas strains have been isolated or detected, the life stage of the beetle, the method of detection (MD) of Pseudomonas and likely roles proposed for Pseudomonas strains, if any. $\mathrm{G}=$ gut; $\mathrm{Ga}=$ gallery; $\mathrm{F}=$ Frass; $\mathrm{B}=$ entire beetle crushed; $\mathrm{P}=$ phloem; $\mathrm{OS}=$ oral secretion; $\mathrm{S}=$ surface of the beetle; $\mathrm{L}=$ larvae; $\mathrm{Pu}=$ pupae; $\mathrm{TA}=$ teneral adult; $\mathrm{PA}=$ pre-emerged adults; $\mathrm{A}=$ adults; $\mathrm{CIA}=$ culture independent method analyses based on amplicon sequencing; $\mathrm{CIS}=$ culture independent method analyses based on shotgun sequencing; $\mathrm{CD}=$ culture dependent method.

\begin{tabular}{|c|c|c|c|c|c|}
\hline Beetle (Tree-Host) & Sample & Life Stage & MD & Functions of Pseudomonas & Reference \\
\hline $\begin{array}{c}\text { Dendroctonus adjunctus (Pinus } \\
\text { hartwegii), D. approximatus (P. teocote), } \\
\text { D. jeffreyi (P. jeffreyi), D. } \\
\text { mesoamericanus (P. teocote), } D . \\
\text { mexicanus }(P \text {. patula), D. parallelocollis } \\
\text { (P. hartwegii), D. ponderosae }(P . \\
\text { strobiformis), D. pseudotsugae } \\
\text { (Pseudotsuga menziesii var. glauca), } D . \\
\text { rhizophagus }(P . \text { arizonica), D. valens }(P . \\
\text { leiophylla), D. vitei (P. pseudostrobus) }\end{array}$ & G & - & CIA & - & [32] \\
\hline D. rhizophagus (P. arizonica) & G & $\mathrm{L}, \mathrm{Pu}, \mathrm{TA}, \mathrm{PA}, \mathrm{EA}$ & CIA & - & [34] \\
\hline D. simplex (Larix $\times$ eurolepis) & Cuticle, Ga & A & CIA & - & [27] \\
\hline D. valens (P. resinosa) & Ga & - & CIA & - & [27] \\
\hline D. valens (P. tabuliformis) & G & A & CIA & $\begin{array}{l}\text { Prediction of metabolic activities } \\
\text { using the PICRUSt method. }\end{array}$ & [35] \\
\hline $\begin{array}{l}\text { Xyleborinus saxeseni, D. ponderosae, } D . \\
\text { frontalis }\end{array}$ & B, Ga & L, A & CIACIS & $\begin{array}{l}\text { They found that Pseudomonas } \\
\text { genome bins reconstructed from } \\
\text { different insects are very similar } \\
\text { (based on Average Nucleotide } \\
\text { Identity (ANI) comparison). }\end{array}$ & [36] \\
\hline $\begin{array}{c}\text { Xyleborus affinis, Xyleborus bispinatus, } \\
\text { and Xyleborus volvulus (artificially } \\
\text { reared) }\end{array}$ & B & A & CIA & $\begin{array}{l}\text { Prediction of metabolic activities } \\
\text { using the PICRUSt method. }\end{array}$ & [37] \\
\hline Xyleborus affinis (artificially reared) & B & A & CIA & $\begin{array}{l}\text { Prediction of metabolic activities } \\
\text { using the PICRUSt method. }\end{array}$ & [33] \\
\hline $\begin{array}{l}\text { D. pondersoae (P. contorta and } P \text {. } \\
\text { contorta }-P \text {. banksiana hybrid) }\end{array}$ & $\mathrm{B}, \mathrm{Ga}$ & A & CIS & $\begin{array}{l}\text { Genetic potential for terpene and } \\
\text { diterpene degradation. }\end{array}$ & [38] \\
\hline D. rhizophagus (P. arizonica) & G & L, A & $\mathrm{CD}$ & $\begin{array}{c}\text { Lipolytic, amylolytic, esterase, } \\
\text { cellulolytic and xylanolytic } \\
\text { activities. }\end{array}$ & [39] \\
\hline D. ponderosae (Pinus sp.) & $\mathrm{B}, \mathrm{Ga}, \mathrm{P}$ & A & $\mathrm{CD}$ & $\begin{array}{l}\text { In vitro degradation of } \\
\text { monoterpenes. }\end{array}$ & [12] \\
\hline $\begin{array}{c}\text { D. valens } \\
\text { (leiophylla) }\end{array}$ & G & - & $\mathrm{CD}$ & $\begin{array}{l}\text { Uricolytic activity. Ability to use } \\
\text { uric acid as sole nitrogen, carbon } \\
\text { and energy source. }\end{array}$ & [40] \\
\hline D. ponderosae (P. contorta) & S & $\mathrm{L}, \mathrm{A}$ & $\mathrm{CD}$ & - & [41] \\
\hline D. armandi (P. armandii) & G & $\mathrm{L}$ & $\mathrm{CD}$ & Cellulolytic activity. & [42] \\
\hline D. valens (Pinus sp.) & G, F & A & $\mathrm{CD}$ & $\begin{array}{l}\text { Verbenone production, } \alpha \text {-pinene } \\
\text { degradation. }\end{array}$ & {$[43,44]$} \\
\hline D. micans (Picea orientalis) & B & $\mathrm{L}, \mathrm{A}$ & $\mathrm{CD}$ & - & [45] \\
\hline $\begin{array}{l}\text { D. rufipennis (Picea sp.), D. ponderosae } \\
\text { (P. contorta) }\end{array}$ & OS & A & $\mathrm{CD}$ & - & [46] \\
\hline $\begin{array}{c}\text { Anisandrus }(=\text { Xyleborus) dispar (Corylus } \\
\text { sp.) }\end{array}$ & B & $\mathrm{L}$ & $\mathrm{CD}$ & - & [47] \\
\hline $\begin{array}{c}\text { D. valens (P. contorta and P. contorta }-P . \\
\text { banksiana hybrids) }\end{array}$ & B & A & $C D$ & $\begin{array}{l}\text { Ability to grow in presence of } \\
\text { monoterpenes. }\end{array}$ & [48] \\
\hline Hylesinus fraxini (Fraxinus excelsior) & B & A & $\mathrm{CD}$ & Cellulolytic activity. & [49] \\
\hline $\begin{array}{l}\text { Cryphalus piceae (Abies alba), Ips } \\
\text { typographus (Picea abies) }\end{array}$ & B & $\mathrm{A}, \mathrm{L}$ & $\mathrm{CD}$ & $\begin{array}{l}\text { Degradation of cellullose, xylan, } \\
\text { starch, and diverse chemical } \\
\text { dyes. }\end{array}$ & [13] \\
\hline D. rufipennis & OS & A & $\mathrm{CD}$ & $\begin{array}{l}\text { Inhibit fungi associated with } \\
\text { mouthparts of the beetle. }\end{array}$ & [25] \\
\hline D. ponderosae (P. contorta) & OS & L, A & $\mathrm{CD}$ & $\begin{array}{l}\text { Promote the growth of some } \\
\text { beetle-associated fungi and } \\
\text { suppress the growth of some } \\
\text { other beetle-associated fungi. }\end{array}$ & [50] \\
\hline
\end{tabular}


Table 1. Cont.

\begin{tabular}{|c|c|c|c|c|c|}
\hline Beetle (Tree-Host) & Sample & Life Stage & MD & Functions of Pseudomonas & Reference \\
\hline D. valens (P. tabuliformis) & S, F, G & $\mathrm{L}$ & $\mathrm{CD}$ & $\begin{array}{c}\text { Inoculation of different strains of } \\
\text { Pseudomonas alleviate the } \\
\text { antagonistic effects of fungi } L \text {. } \\
\text { procerum and O. minus on larva } \\
\text { growth. } \\
\text { They show a direct inhibition of } \\
\text { O. minus growth. } \\
\text { They show that the D-pinitol and } \\
\text { D-glucose consumption of } O \text {. } \\
\text { minus is decreased, while the } \\
\text { D-pinitol consumption of } L . \\
\text { procerum is increased when } \\
\text { bacteria is inoculated. }\end{array}$ & [28] \\
\hline I. sexdentatus (P. orientalis) & B & A & $\mathrm{CD}$ & $\begin{array}{l}\text { One isolate increase } \\
\text { significatively the mortality when } \\
\text { is inoculated into larvae.Another } \\
\text { one do not increase significatively } \\
\text { the mortality. }\end{array}$ & [51] \\
\hline D. valens & - & - & $\mathrm{CD}$ & $\begin{array}{l}\text { Pseudomonas volatiles decrease } \\
\text { the growth of } O \text {. minus and, } \\
\text { therefore, to increase the growth } \\
\text { of larvae when } O \text {. minus is } \\
\text { present. }\end{array}$ & [52] \\
\hline D. valens & - & - & $\mathrm{CD}$ & $\begin{array}{l}\text { Pseudomonas volatiles decrease } \\
\text { the growth of } L \text {. procerum and, } \\
\text { therefore, to increase the growth } \\
\text { of larvae when L. procerum is } \\
\text { present. }\end{array}$ & [53] \\
\hline D. ponderosae & $\mathrm{B}, \mathrm{Ga}$ & - & $\mathrm{CD}$ & $\begin{array}{l}\text { Inoculation of different strains of } \\
\text { Pseudomonas in P. contorta and in } \\
\text { P. banksiana, reduced antagonistic } \\
\text { effects by Aspergillus and } \\
\text { Trichoderma resulting in more } \\
\text { larvae and longer ovipositional } \\
\text { and larval Ga. }\end{array}$ & [54] \\
\hline $\begin{array}{c}\text { Ips acuminatus (P. sylvestris), Pityogenes } \\
\text { bidentatus (P. sylvestris) }\end{array}$ & B & A & $\mathrm{CD}$ & $\begin{array}{l}\text { Ability to inhibit other } \\
\text { microorganisms and genetic } \\
\text { potential to produce } \\
\text { antimicrobial compounds. }\end{array}$ & [29] \\
\hline Ips pini (P. resinosa) & G & $\mathrm{P}, \mathrm{A}$ & $\mathrm{CD}$ & - & [55] \\
\hline $\begin{array}{l}\text { Hypothenemus hampei (Coffea arabica, } \\
\text { Coffea arabica var limani, C. congensis } \times \\
\text { C. canephora), H. eruditus (Cecropia } \mathrm{sp} .) \text {, } \\
\text { Scolytodes maurus (Cecropia sp.) }\end{array}$ & $\mathrm{B}$ & - & CD CIA & $\begin{array}{l}\text { In vitro and in vivo } \\
\text { caffeine-degradation (use as sole } \\
\text { source of } C \text { and } N \text { ). }\end{array}$ & [56] \\
\hline $\begin{array}{l}\text { Ips duplicatus, I. typographus and } \\
\text { Polygraphus poligraphus (Picea abies), I. } \\
\text { acuminatus and I. sexdentatus (Pinus } \\
\text { sylvestris), I. cembrae (Larix decidua). }\end{array}$ & G & A & CIA & $\begin{array}{l}\text { Prediction of metabolic activities } \\
\text { using the PICRUSt method. }\end{array}$ & [57] \\
\hline D. frontalis (P. taeda) & G & A & CD CIA & - & [58] \\
\hline
\end{tabular}

The bark beetle cultivable bacteriome has been studied mainly in individuals belonging to the genus Dendroctonus and there is a plethora of studies reporting the isolation of bacteria classified as Pseudomonas from this beetle. Pseudomonas strains have been found in D. rhizophagus collected from Pinus arizonica trees [26,39], oral secretions, surface, whole bodies, and galleries of D. ponderosae $[41,50,54]$ and its tree host (Pinus contorta) phloem [12]; in gut, frass, surface, or whole bodies of $D$. valens in different life stages $[28,30,40,43,48,52,53,59]$; in the gut of $D$. armandi larvae [42]; in D. micans larvae and adults collected from Picea orientalis [46]; in D. rufipennis (collected from Picea sp.) and in D. pondersoae (sampled from Pinus contorta) oral secretions [25,46]; and in the gut of adults (but not larvae) of D. frontalis (obtained from galleries excavated in Pinus taeda) [58].

Apart from Dendroctonus beetles, Ceja-Navarro et al. [56] isolated Pseudomonas from the coffee berry borer (Hypothenemus hampei). Delalibera et al. [55] reported the presence of Pseudomonas strains in the guts of Ips pini pupae and adults. Sevim et al. [60] isolated Pseudomonas from crushed adults of I. sexdentatus living on Picea orientalis and Fabryová et al. [11] from adult specimens of Cryphalus piceae (Abies alba) and Ips typographus (Picea abies). Additionally, Pseudomonas bacteria have been isolated from Pityogenes 
bidentatus, Ips, Hypothenemus, and Scolytodes beetles [29,56,57] and experiments carried out in our laboratory showed the presence of Pseudomonas in I. typographus, I. cembrae, and in Xylocleptes bispinus (unpublished data).

Apart from phloeophagous bark beetles, Pseudomonas spp. have been cultivated from adults or larvae of ambrosia beetles such as Xyleborus affinis, X. dispar, and Xylosandrus germanus collected on hazelnut trees (Corylus avellana) [47,51,61].

Most of the previous ecological studies approach the analysis of the beetles' microbiota through a single gene sequence taxonomic approach. However, broader polyphasic approaches have been applied in a few studies, which led to the discovery of novel species within the genus Pseudomonas such as P. coleopterorum, which was first isolated from Hylesinus fraxini [49], P. typographi discovered from Ips typographi [62], and P. bohemica, cultivated from I. acuminatus beetles [29].

Apart from the above-mentioned studies based on the isolation of the beetle bacterial associates, some other analysis of the microbial diversity associated with bark beetles based on culture-independent methods have detected the presence of Pseudomonas in the bark beetle holobiont (Table 1). Culture-independent approaches are based on massive sequencing of target genes (i.e., $16 \mathrm{~S}$ rRNA gene, in the case of bacterial diversity studies) or on the shotgun sequencing of the whole DNA from the samples [33,63-65]. The major advantage of this latter approach is that it allows the inference of the functions linked to the microbiota [66] by comparison of the sequenced genes with databases of gene families and reference genomes.

Shotgun metagenomics in D. ponderosae beetles and galleries from different tree hostsPinus contorta (lodgepole pine) and Pinus contorta-Pinus banksiana (Hybrid pine)-and different locations showed Pseudomonas sequences being up to $60 \%$ of the total obtained bacterial sequences [38].

Aylward et al. [36] carried out a multi-platform analysis of different insects by combining 16S rRNA meta-barcoding and shotgun metagenome sequencing over larvae, adults, and galleries. They found that Pseudomonas sequences were predominant, not only in southern pine beetles and mountain pine beetles $(60-95 \%$ of the sequences belongs to the family Pseudomonadaceae), but also in ambrosia beetles, fungus-growing ants, and termites. They also studied the phylogeny of reconstructed Pseudomonas genome bins, with average nucleotide identity (ANI) values up to $98 \%$ shared among pseudomonads of different origins, suggesting a functional convergence toward this microbe-host interaction.

Based on 16S rRNA amplicon sequencing analyses, Pseudomonas bacteria have been encountered in several Dendroctonus species (from different tree hosts): D. frontalis (Pinus taeda) [58], D. adjunctus (Pinus hartwegii), D. approximatus (Pinus teocote), D. jeffreyi (Pinus jeffreyi), D. mesoamericanus (Pinus teocote), D. mexicanus (Pinus patula), D. parallelocollis (Pinus hartwegii), D. ponderosae (Pinus strobiformis), D. pseudotsugae (Pseudotsuga menziesii var. glauca), D. rhizophagus (Pinus arizonica), D. valens (Pinus leiophylla), and D. vitei (Pinus pseudostrobus) [32], larvae, pupae, teneral adults, and pre-emerged and emerged adults of D. rhizophagus (Pinus arizonica) [34], crushed adults and larvae of D. punctatus, D. micans and D. valens [59], and cuticle and galleries of D. simplex (Larix $\times$ Eurolepis) [27].

Recently, $\mathrm{Xu}$ et al. [35] suggested that bacteria from the genus Pseudomonas are relevant members of the core microbiome in D. valens, finding that nearly $50 \%$ of the sequences obtained from larvae and adults belonged to this bacterial genus. Interestingly, these authors identified P. bohemica as one of the most abundant OTUs, this being a species first isolated from another bark beetle, Ips acuminatus [29]. Similarly, Mason et al. [30] found a higher proportion of pseudomonads in the galleries made by this beetle in Pinus resinosa than in the intact tree phloem.

Ceja-Navarro and colleagues [56], also using 16S rRNA amplicon sequencing, found that the genus Pseudomonas was prevalent in the core microbiome of Hypothenemus hampei isolated from different coffee trees worldwide (Coffea arabica, C. arabica var limaní, and C. congensis $\times C$. canephora). However, using the same method and marker, Pseudomonas was found to be inconsistently associated with adults and eggs of the ambrosia beetle Xyleborus 
affinis [33] and a similar study over a most extended set of artificially reared ambrosia beetles (Xyleborus affinis, X. bispinatus, and X. volvulus) showed that Pseudomonas is a rather uncommon symbiont, whose abundance is highly affected by the cultivation media used for the in vitro rearing [37].

Overall, considering studies based in both culture-dependent and independent methods, Pseudomonas bacteria have been encountered in 35 different bark beetle species from 11 genera (Anisandrus, Dendroctonus, Ips, Xyleborinus, Hylesinus, Xyleborus, Xylocleptes, Pityogenes, Cryphalus, Hypothenemus, and Scolytodes), which had been collected from 24 different tree species from nine different genera (Pinus, Pseudotsuga, Coffea, Cecropia, Corylus, Larix, Fraxinus, Abies, and Picea). Several of the reported studies did not separate different beetle tissues; however, based on the works in which a dissection of different beetle body-sites has been performed, we can conclude that bacteria belonging to Pseudomonas are associated with the bark beetles' guts, cuticle, and oral secretions.

It is important to say that the above-mentioned culture independent analyses of the bark beetle bacteriome are based on short sequences of $16 \mathrm{~S}$ rRNA amplicon fragments. These sequences do not allow a robust classification of the sequences at species level [67]. To obtain the most accurate identification at species level, there are nowadays massive parallel sequencing platforms with the potential to obtain nearly complete $16 \mathrm{~S}$ rRNA gene sequences ( 1500 bp), which allow a better identification of the microbiome at species level $[35,37,68]$. Moreover, amplicons of Pseudomonas housekeeping genes such as rpoB, $r p o D$, and $g y r B$ [49] can be obtained for a more accurate identification at species level of those bacterial strains belonging to Pseudomonas. A more reliable identification at species level of the Pseudomonas associated with bark beetles will allow the analysis of a potential coevolution between Pseudomonas and Scolytidae.

In any case, based on all of the above-mentioned studies, we can conclude that bacteria from the genus Pseudomonas are widespread over bark beetles, being possibly part of the stable microbiome of these insects. Thus, it is possible that the existence of a co-evolution between bacteria from the genus Pseudomonas and bark beetles, in which the insects might have acquired abilities to survive and compete in their niches due to the bacterial metabolism and, similarly, the bacteria, might have gained fitness from their association with the host. However, further research should be made to prove an existing stable association between bark beetle species and Pseudomonas, in order to distinguish true coevolved associations from serendipitous, transient ones. For instance, sampling a beetle species along different locations and environmental conditions as well as life cycle stages would allow us to determine if certain Pseudomonas species belong to the core microbiome of the beetle species, and therefore to support the coevolution between the microbe and its host.

\section{Role of Pseudomonas in the Nutrition of Bark Beetles}

Bark beetles feed under the bark of their host trees, specifically on their phloem and/or their xylem $[69,70]$. The other dominant live strategy is that of ambrosia beetles, which nutritionally depend on cultivated ambrosia fungi [71]. Since the ingested plant tissues are constituted by complex molecules, insects are unable to easily degrade them [39]. However, they may get help: as a result of their enzymatic machinery, microbes present in the bark beetle holobiont can hydrolyze these complex tree polymers into more simple sugars, which can then be more available as nutrients to the insect host $[9,11,39]$. The most abundant polymers in the tree tissues, which the beetles feed on, are cellulose, xylan, and starch [11]. These polymers can be degraded by microbial enzymes: cellulose is degraded by cellulolytic enzymes called cellulases [49], xylan, the main component of hemicelluloses [72], by xylanases, and starch, another relevant polymer of plants, which is stored in granules, is digested by amylases [73,74].

In this sense, some Pseudomonas strains isolated from bark beetles have been suggested to play a key role in the nutrition of its host (Table 1, Figure 1). For instance, P. coleopterorum, associated with Hylesinus fraxini, and Pseudomonas spp., isolated from the gut of D. armandi, have been characterized for their in vitro cellulolytic activity [42,49]. Additionally, in a 
broad study including many bacterial isolates from C. piceae and I. typographus, strains from the species Pseudomonas arsenicoxydans and Pseudomonas trivialis were able to degrade cellulose, xylan, and starch. These activities were detected by hydrolysis halos in Petri dishes containing these compounds. In a similar research, Pseudomonas strains closely related to P. putida and P. azotoformans species, isolated from larvae and adults' guts from $D$. rhizophagus, were proven to have lipolytic, amylolytic, esterase, cellulolytic, and xylanolytic activities in vitro [39]. All these activities are related to the degradation of commonly available organic nutrients in the host tree of these beetles.

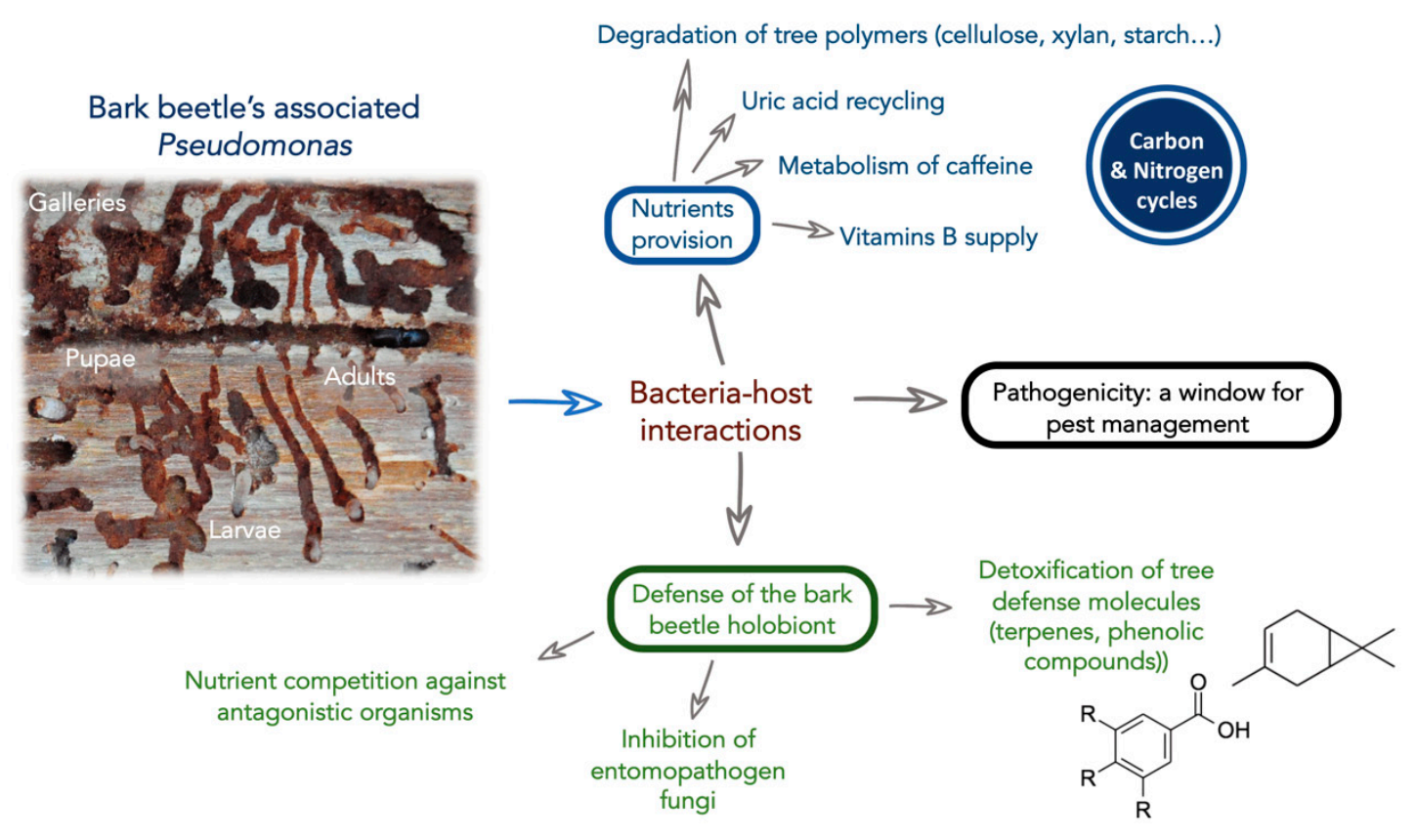

Figure 1. Scheme representing overall potential functions Pseudomonas in the bark beetle holobiont.

In addition to the degradation of complex plant polymers, Pseudomonas bacteria isolated from Hypothenemus hampei-beetles inhabiting coffee trees-can use caffeine as a sole source of carbon $(\mathrm{C})$ and nitrogen $(\mathrm{N})$ when grown in vitro. Indeed, when a Pseudomonas strain is inoculated into antibiotic-treated beetles, previously proven to be unable to metabolize caffeine, the ability to digest this molecule is restored, likely because of the ability of this bacterium to produce caffeine demethylase enzymes [56].

Furthermore, in vitro tests proved that Pseudomonas from the guts of $D$. valens can use uric acid as a sole source of energy, C, and N [40]. Since bark beetles excrete uric acid as a waste compound, this phenomenon may lead to its recycling and the authors suggest a contribution of these bacteria to the insect $\mathrm{N}$ balance, since its niche within the tree host is limited in N [40]. Beetles could assimilate recycled ammonium through the enzyme glutamine synthetase, combining ammonium and glutamate to form glutamine. However, the use of bacteria-mediated ammonium supply for the insect host has never been tested. As García-Fraile already pointed out [9], in vivo assays using gnotobiotic beetles inoculated with the Pseudomonas strains and uric acid labelled with the ${ }^{15} \mathrm{~N}$ stable isotope could allow for proof that the incorporation of ${ }^{15} \mathrm{~N}$ in the amino acids of the beetle is due to the bacterial capability to recycle uric acid.

Apart from $\mathrm{C}$ and $\mathrm{N}$ supply, another possible contribution to the bark beetle nutrition is the synthesis of vitamins. Many Pseudomonas strains have been characterized because of their ability to produce B-group vitamins [75-79]. The putative ability to produce B group vitamins and amino acids essential for insects was predicted in Pseudomonas associates of $X$. affinis [33]. In that study, the bacterial metabolic functions were predicted based on $16 \mathrm{~S}$ rRNA sequences using the database of reference genomes. Thus, although to the best of our knowledge, the literature lacks studies directly reporting the relevance of these metabolic 
capabilities to beetle nutrition, the contribution of Pseudomonas to its host nutrition through the supply of vitamins and essential amino acids could be hypothesized, although rigorous in vivo tests to prove this hypothesis should be performed.

Most bark beetles are usually associated with Ophiostomatales fungi in a symbiotic relationship in which the beetle feeds on the fungi [44]. Interestingly, Adams and collaborators [50] showed how Pseudomonas spp. are able to both inhibit or promote the growth of different bark beetle fungal symbionts, depending on the fungal species and/or the presence of $\alpha$-pinene: Pseudomonas spp. decreases the growth of Ophiostoma montium, but increases the growth of Grosmannia clavigera and Leptographium procerum when no $\alpha$-pinene is present in the assay; notwithstanding, the bacterium increases the growth of all three fungi including also O. montium, plus Ophiostoma ips, when the bacterial treatment is combined with $\alpha$-pinene.

All capabilities of bark beetle pseudomonads associates could be implicated in the promotion of beetle nutrition. Nonetheless, whether Pseudomonas strains of bark beetles play these roles in nutrition lacks rigorous research. These studies might include in vivo tests using gnotobiotic beetles inoculated with the Pseudomonas strains predicted to aid in nutrition and knock-out mutants in the metabolic pathways potentially implicated in the benefit to compare the beetle's fitness in both cases.

\section{Role of Pseudomonas in the Detoxification of the Bark Beetle Environment and in Pheromone Production}

Trees are not passive to the massive attacks of bark beetles. They have many defenses including the production of volatile molecules such as phenolic compounds and terpenes, which are toxic to the beetles [9]. Nevertheless, these insects have some level of tolerance to these compounds [80]. Indeed, at low concentrations, these molecules are detected from adult beetles and help them to locate weakened host trees [9]. In addition, bark beetles produce pheromone molecules as a by-product of the degradation of host monoterpenes [81]. Several research studies have suggested that some bacteria associated with these insects are involved in the metabolization of tree defense compounds, which seems to result in the detoxication of the bark beetle's environment [9].

It has been demonstrated that Pseudomonas inhabiting in the gut and frass of $D$. valens are able to metabolize the terpenes $\alpha$-pinene and cis-verbenol and that cis-verbenol is converted to verbenone, a pheromone compound for bark beetles [43,82]. Although these biological activities were mainly demonstrated by in vitro tests [43,82], they are also supported by targeted metabolomic experiments carried out with $D$. valens guts with a large abundance of Pseudomonas in comparison to antibiotic-treated guts (guts without microbial associates) [41].

Similarly, Pseudomonas isolated from D. ponderosae decreased concentrations of the tree defense compounds 3-carene, (-)- $\alpha$-pinene, $(+)-\alpha$-pinene, and (-)- $\beta$-pinene in liquid cultures [12]. In addition, a Pseudomonas strain isolated from the red turpentine beetle ( $D$. valens) was proven to grow in the presence of $1-5 \%$ of the monoterpenes $\alpha$-pinene, myrcene, and 3-carene, and with a reduced growth in the presence of limonene and $\beta$-pinene [48].

Furthermore, this ability to degrade terpenes has also been studied through a shotgun metagenome analyses. Adams and colleagues [38] obtained samples of D. ponderosae adults, galleries, and unattacked tree phloem from different sites and compared their metagenome sequences. They found that samples associated with beetles were enriched in functions related with limonene and pinene degradation as well as genes belonging to the dit gene cluster, a well-characterized machinery involved in the degradation of diterpenes [83]. Indeed, most of these genes were taxonomically classified to Pseudomonas bacteria.

Based on all these studies, Pseudomonas seems to be broadly related with the chemical detoxification of the beetle's environment, facilitating the survival of their insect host inside the tree (Table 1, Figure 1). 


\section{Role of Pseudomonas in the Defense of the Bark Beetle Holobiont against Pathogens}

Tree chemical compounds are not the only dangers that bark beetles face; although these insects establish beneficial interactions with some fungi $[84,85]$, some others are their antagonists, either causing disease or competing for nutrients $[9,10]$. In these detrimental associations, bacteria can serve as a defense for the beetle because of their ability to inhibit some of these fungal enemies $[9,13,47,86]$.

Among these protective bacteria, Pseudomonas are important allies. Some volatile compounds produced by Pseudomonas isolated from $D$. valens decrease the in vitro growth of the antagonistic fungi Ophiostoma minus and Leptographium procerum [52,53]. Moreover, these Pseudomonas strains also have the ability to increase the growth of larvae inoculated with O. minus or L. procerum [52,53]. Similar findings were demonstrated by Zhou and collaborators [28]: apart from the alleviation of these fungal antagonistic effects, the authors showed how the consumption of D-pinitol and D-glucose by O. minus seemed decreased in the presence of pseudomonads, while, surprisingly, they forced L. procerum to consume D-pinitol prior to the consumption of D-glucose, which is hypothesized to remain available for the beetle.

Additionally, other fungi can also be influenced by the presence of Pseudomonas: inoculation of these bacteria into $D$. ponderosae larvae reduced the antagonistic effects of Aspergillus and Trichoderma, which led to more larvae and longer galleries. This effect was also observed in the new beetle tree host, jak pine (Pinus banksiana), recently accessed due to warming climate; this suggests that climate-driven expansion of $D$. ponderosae will not be significantly limited by the requirements of these beneficial bacterial associates [54].

Additionally, Pseudomonas strains isolated from Ips acuminatus, Pityogenes bidentatus, and Cryphalus piceae inhibit the growth of Aspergillus sp. in vitro [29]. Finally, Pseudomonas chlororaphis, a species associated with bark beetles [61] together with other pseudomonads, are known for their nematocidal activity [86,87], which could suggest a possible involvement of these bacteria in the control of bark beetle pathogenic nematodes.

Still on this subject, an in vitro test demonstrated that a Pseudomonas viridiflava strain isolated from oral secretions of $D$. rufipennis decreased the growth of four gallery-invasive fungal species: Leptographium abietinum, Aspergillus fumigatus, Aspergillus nomius, and Trichoderma harzianum [25]. These findings were obtained while the authors investigated the antifungal activity of the bark beetles' oral secretions against these fungi, demonstrating that the antifungal activity appeared in non-filtered oral secretions and it disappeared when filter-sterilization was applied. Thus, bacteria from oral secretions, and among them, the species Pseudomonas viridiflava, seem to protect the beetle against these pathogenic fungi.

All these data suggest a role of Pseudomonas in the bark beetles' pathogen exclusion (Table 1). This protective role of Pseudomonas and other bark beetle associated bacteria might in part explain the fact that entomopathogenic fungi, when applied as biocontrol agents for bark beetle forest pests, have high differences in effectiveness among distinct bark beetle species [88]. The application of this knowledge in integrated biocontrol strategies, targeting not only the beetle, but also its potential protective symbionts, may lead to an alleviation in the variations of susceptibility of bark beetles to entomopathogenic fungi.

\section{Pathogenic Pseudomonas: Potential as Biocontrol Agents for Bark Beetle Pests}

Along the previous sections of this review, we bring the idea of the potential benefiting roles of bacteria from the genus Pseudomonas for the bark beetle holobiont. However, with more than 200 validated species, Pseudomonas is a very broad bacterial genus with very diverse metabolic capabilities and lifestyles, and there is a plethora of studies in which the ability of Pseudomonas strains to become insect entomopathogens has been reported $[22,89,90]$.

Among them, strains of the P. fluorescens group of species are well known insect pathogens. For instance, a study performed by Sevim et al. [60] demonstrated that the inoculation of a strain of P. fluorescens was capable of increasing the mortality of Ips sexdentatus larvae up to $73 \%$. This strain with insecticidal activity was isolated from I. sexdentatus 
with disease symptoms. Therefore, this bacterium provides an opportunity to be used as a biocontrol agent against this forest pest.

Although existing literature on this research topic is scarce, the above-mentioned studies show the potential of bacterial strains as biocontrol agents against bark beetle pests. In this sense, Pseudomonas strains belonging to well-known entomopathogenic species could be effective agents to be integrated in pest management strategies.

In this sense, field experiments analyzing the efficiency of these bacteria as biocontrol agents and the comparison of their use with other already applied methods to control this pest or even their inclusion in integrated pest management strategies should be addressed.

\section{Conclusions and Future Perspectives}

As occurs in many other environments, strains belonging to the genus Pseudomonas seem to have adapted to live in association with bark beetles, since they are present in most of the reports on the bacterial biodiversity associated with bark beetles. Pseudomonas strains are widespread among many different species of beetles from the Scolytinae subfamily, dispersed worldwide in different tree host species.

According to the available literature, many of these bacteria seem to be able to benefit their insect hosts by providing them with nutrients, detoxifying their microenvironment and protecting them from entomopathogens or antagonistic microbes. These reports support a predicted relevance of this genus in the bark beetles' life cycle.

However, many of the predicted functions of Pseudomonas bacteria in the bark beetle holobiont are based on in vitro and in silico assays; thus, further experiments should be performed to prove whether these predictions occur in nature.

Current and future knowledge on the Pseudomonas-bark beetle interaction can be very useful, not only because of the inherent value of the knowledge in basic and environmental sciences, but also to aid finding the needed solutions to overcome bark beetle forest pests (either through the application of pathogenic Pseudomonas such as Biocontrol Agents (BCAs), or by targeting the elimination of beneficial Pseudomonas providing fitness to their host, weaking the beetle as the base for other biocontrol strategies).

Hence, this review aims to serve as a motivation for the development of deeper analyses in this research field to test the above-mentioned hypothesis on the role of Pseudomonas within the bark beetle holobiont. For instance, in vivo tests using gnotobiotic insects inoculated with the pseudomonad isolates could provide some insights into the influence of each organism to its counterpart and the application of omics techniques such as transcriptomics, metabolomics, and proteomics. Experiments with isotope labelled molecules might aid in the description of the molecular dialogue between both organisms.

It is also important to point out that despite the extensive literature focus on the benefits of the Pseudomonas-bark beetle association for the host, there is a knowledge gap on the benefits for the bacterial (Pseudomonas) counterpart of the bark beetle holobiont; the description of a mutual benefit would be important to define the existence of a possible mutualistic symbiosis between the macro- and the microsymbiont.

Author Contributions: Z.S.-S. and P.G.-F. gathered information, analyzed data, conceptualized, and wrote the manuscript. M.K. and R.R. provided revisions, suggestions, editions, and comments. All authors have read and agreed to the published version of the manuscript.

Funding: This research was funded by the Czech Science Foundation (GAČR), grant number GAČRSenior 19-09072S. The researchers also thank the Excellence Unit of the Spanish-Portuguese Institute for Agricultural Research (CIALE) (CLU-2018-04) for the provision of research facilities. ZSS received a grant from the Junta de Castilla y León, Spanish Regional Government.

Conflicts of Interest: The authors declare no conflict of interest. 


\section{References}

1. Weed, A.S.; Ayres, M.P.; Hicke, J.A. Consequences of climate change for biotic disturbances in North American forests. Ecol. Monogr. 2013, 83, 441-470. [CrossRef]

2. Biedermann, P.H.; Müller, J.; Grégoire, J.C.; Gruppe, A.; Hagge, J.; Hammerbacher, A.; Hofstetter, R.W.; Kandasamy, D.; Kolarik, M.; Kostovcik, M.; et al. Bark beetle population dynamics in the Anthropocene: Challenges and solutions. Trends Ecol. Evol. 2019, 34, 914-924. [CrossRef]

3. Lindgren, B.S.; Raffa, K.F. Evolution of tree killing in bark beetles (Coleoptera: Curculionidae): Trade-offs between the maddening crowds and a sticky situation. Can. Entomol. 2013, 145, 471-495. [CrossRef]

4. Raffa, K.F.; Gregoire, J.C.; Lindgren, B.S. Natural history and ecology of bark beetles. In Bark Beetles; Academic Press: Cambridge, MA, USA, 2015; pp. 1-40.

5. Byers, J.A. Host-tree chemistry affecting colonization in bark beetles. In Chemical Ecology of Insects 2; Springer: Boston, MA, USA, 1995; pp. 154-213.

6. Schmidt, K.; Engel, P. Mechanisms underlying gut microbiota-host interactions in insects. J. Exp. Biol. 2021, 224, jeb207696. [CrossRef] [PubMed]

7. Chakraborty, A.; Roy, A. Microbial Influence on Plant-Insect Interaction. In Plant-Pest Interactions: From Molecular Mechanisms to Chemical Ecology; Springer: Singapore, 2021; pp. 337-363.

8. Weisskopf, L.; Schulz, S.; Garbeva, P. Microbial volatile organic compounds in intra-kingdom and inter-kingdom interactions. Nat. Rev. Microbiol. 2021, 1-14. [CrossRef]

9. García-Fraile, P. Roles of bacteria in the bark beetle holobiont-how do they shape this forest pest? Ann. Appl. Biol. 2018, 172, 111-125. [CrossRef]

10. Six, D.L. The bark beetle holobiont: Why microbes matter. J. Chem. Ecol. 2013, 39, 989-1002. [CrossRef]

11. Fabryová, A.; Kostovčík, M.; Díez-Méndez, A.; Jiménez-Gómez, A.; Celador-Lera, L.; Saati-Santamaría, Z.; Sechovcová, H.; Menéndez, E.; Kolařik, M.; García-Fraile, P. On the bright side of a forest pest-the metabolic potential of bark beetles' bacterial associates. Sci. Total Environ. 2018, 619, 9-17. [CrossRef]

12. Boone, C.K.; Keefover-Ring, K.; Mapes, A.C.; Adams, A.S.; Bohlmann, J.; Raffa, K.F. Bacteria associated with a tree-killing insect reduce concentrations of plant defense compounds. J. Chem. Ecol. 2013, 39, 1003-1006. [CrossRef] [PubMed]

13. Scott, J.J.; Oh, D.C.; Yuceer, M.C.; Klepzig, K.D.; Clardy, J.; Currie, C.R. Bacterial protection of beetle-fungus mutualism. Science 2008, 322, 63. [CrossRef]

14. Veselská, T.; Skelton, J.; Kostovčík, M.; Hulcr, J.; Baldrian, P.; Chudíčková, M.; Cajthamlad, T.; Vojtováa, T.; Garcia-Fraile, P.; Kolařík, M. Adaptive traits of bark and ambrosia beetle-associated fungi. Fungal Ecol. 2019, 41, 165-176. [CrossRef]

15. Silby, M.W.; Winstanley, C.; Godfrey, S.A.; Levy, S.B.; Jackson, R.W. Pseudomonas genomes: Diverse and adaptable. FEMS Microbiol. Rev. 2011, 35, 652-680. [CrossRef] [PubMed]

16. Loper, J.E.; Hassan, K.A.; Mavrodi, D.V.; Davis, E.W. Comparative genomics of plant-associated Pseudomonas spp.: Insights into diversity and inheritance of traits involved in multitrophic interactions. PLoS Genet. 2012, 8, e1002784. [CrossRef]

17. Barbier, M.; Damron, F.H.; Bielecki, P.; Suárez-Diez, M.; Puchałka, J.; Albertí, S.; dos Santos, V.M.; Goldberg, J.B. From the environment to the host: Re-wiring of the transcriptome of Pseudomonas aeruginosa from $22^{\circ} \mathrm{C}$ to $37^{\circ} \mathrm{C}$. PLoS ONE 2014, 9, e89941. [CrossRef]

18. Crone, S.; Vives-Flórez, M.; Kvich, L.; Saunders, A.M.; Malone, M.; Nicolaisen, M.H.; Martínez-García, E.; Rojas-Acosta, C.; Catalina Gomez-Puerto, M.; Calum, H.; et al. The environmental occurrence of Pseudomonas aeruginosa. Apmis 2020, 128, 220-231. [CrossRef]

19. Mercado-Blanco, J.; Bakker, P.A. Interactions between plants and beneficial Pseudomonas spp.: Exploiting bacterial traits for crop protection. Antonie Van Leeuwenhoek 2007, 92, 367-389. [CrossRef]

20. Xin, X.F.; Kvitko, B.; He, S.Y. Pseudomonas syringae: What it takes to be a pathogen. Nat. Rev. Microbiol. 2018, 16, 316. [CrossRef]

21. Huszczynski, S.M.; Lam, J.S.; Khursigara, C.M. The Role of Pseudomonas aeruginosa Lipopolysaccharide in Bacterial Pathogenesis and Physiology. Pathogens 2020, 9, 6. [CrossRef]

22. Dieppois, G.; Opota, O.; Lalucat, J.; Lemaitre, B. Pseudomonas entomophila: A versatile bacterium with entomopathogenic properties. In Pseudomonas; Springer: Dordrecht, The Netherlands, 2015; pp. 25-49.

23. Kamarajan, B.P.; Muthusamy, A. Survival strategy of Pseudomonas aeruginosa on the nanopillar topography of dragonfly (Pantala flavescens) wing. AMB Express 2020, 10, 85. [CrossRef]

24. Kim, H.R.; Lee, H.M.; Yu, H.C.; Jeon, E.; Lee, S.; Li, J.; Kim, D.H. Biodegradation of Polystyrene by Pseudomonas sp. Isolated from the Gut of Superworms (Larvae of Zophobas atratus). Environ. Sci. Technol. 2020, 54, 6987-6996. [CrossRef]

25. Cardoza, Y.J.; Klepzig, K.D.; Raffa, K.F. Bacteria in oral secretions of an endophytic insect inhibit antagonistic fungi. Ecol. Entomol. 2006, 31, 636-645. [CrossRef]

26. Morales-Jiménez, J.; Zúñiga, G.; Ramírez-Saad, H.C.; Hernández-Rodríguez, C. Gut-associated bacteria throughout the life cycle of the bark beetle Dendroctonus rhizophagus Thomas and Bright (Curculionidae: Scolytinae) and their cellulolytic activities. Microb. Ecol. 2012, 64, 268-278. [CrossRef]

27. Durand, A.A.; Bergeron, A.; Constant, P.; Buffet, J.P.; Déziel, E.; Guertin, C. Surveying the endomicrobiome and ectomicrobiome of bark beetles: The case of Dendroctonus simplex. Sci. Rep. 2015, 5, 17190. [CrossRef] 
28. Zhou, F.; Lou, Q.; Wang, B.; Xu, L.; Cheng, C.; Lu, M.; Sun, J. Altered carbohydrates allocation by associated bacteria-fungi interactions in a bark beetle-microbe symbiosis. Sci. Rep. 2016, 6, 20135.

29. Saati Santamaría, Z.; López-Mondéjar, R.; Jiménez Gómez, A.; Méndez, A.D.; Větrovský, T.; Igual, J.M.; Velázquez, E.; Kolarik, M.; Rivas, R.; García-Fraile, P. Discovery of phloeophagus beetles as a source of Pseudomonas strains that produce potentially new bioactive substances and description of Pseudomonas bohemica sp. nov. Front. Microbiol. 2018, 9, 913. [CrossRef]

30. Mason, C.J.; Hanshew, A.S.; Raffa, K.F. Contributions by host trees and insect activity to bacterial communities in Dendroctonus valens (Coleoptera: Curculionidae) galleries, and their high overlap with other microbial assemblages of bark beetles. Environ. Entomol. 2016, 45, 348-356. [CrossRef] [PubMed]

31. Hulcr, J.; Rountree, N.R.; Diamond, S.E.; Stelinski, L.L.; Fierer, N.; Dunn, R.R. Mycangia of ambrosia beetles host communities of bacteria. Microb. Ecol. 2012, 64, 784-793. [CrossRef]

32. Hernández-García, J.A.; Briones-Roblero, C.I.; Rivera-Orduña, F.N.; Zúñiga, G. Revealing the gut bacteriome of Dendroctonus bark beetles (Curculionidae: Scolytinae): Diversity, core members and co-evolutionary patterns. Sci. Rep. 2017, 7, 13864. [CrossRef]

33. Ibarra-Juarez, L.A.; Burton, M.A.J.; Biedermann, P.H.W.; Cruz, L.; Desgarennes, D.; Ibarra-Laclette, E.; Latorre, A.; Alonso-Sánchez, A.; Villafan, E.; Hanako-Rosas, G.; et al. Evidence for Succession and Putative Metabolic Roles of Fungi and Bacteria in the Farming Mutualism of the Ambrosia Beetle Xyleborus affinis. mSystems 2020, 5, e00541-20. [CrossRef] [PubMed]

34. Briones-Roblero, C.I.; Hernández-García, J.A.; Gonzalez-Escobedo, R.; Soto-Robles, L.V.; Rivera-Orduña, F.N.; Zúñiga, G. Structure and dynamics of the gut bacterial microbiota of the bark beetle, Dendroctonus rhizophagus (Curculionidae: Scolytinae) across their life stages. PLOS ONE 2017, 12, e0175470. [CrossRef]

35. Xu, L.; Sun, L.; Zhang, S.; Wang, S.; Lu, M. High-Resolution Profiling of Gut Bacterial Communities in an Invasive Beetle using PacBio SMRT Sequencing System. Insects 2019, 10, 248. [CrossRef]

36. Aylward, F.O.; Suen, G.; Biedermann, P.H.; Adams, A.S.; Scott, J.J.; Malfatti, S.A.; del Rio, T.G.; Tringe, S.G.; Poulsen, M.; Raffa, K.F.; et al. Convergent bacterial microbiotas in the fungal agricultural systems of insects. mBio 2014, 5, e02077-14. [CrossRef]

37. Ibarra-Juarez, L.A.; Desgarennes, D.; Vázquez-Rosas-Landa, M.; Villafan, E.; Alonso-Sánchez, A.; Ferrera-Rodríguez, O.; Moya, A.; Carrillo, D.; Cruz, L.; Carrión, G.; et al. Impact of rearing conditions on the ambrosia beetle's microbiome. Life 2018, 8, 63. [CrossRef] [PubMed]

38. Adams, A.S.; Aylward, F.O.; Adams, S.M.; Erbilgin, N.; Aukema, B.H.; Currie, C.R.; Suen, G.; Raffa, K.F. Mountain pine beetles colonizing historical and naive host trees are associated with a bacterial community highly enriched in genes contributing to terpene metabolism. Appl. Environ. Microbiol. 2013, 79, 3468-3475. [CrossRef] [PubMed]

39. Briones-Roblero, C.I.; Rodríguez-Díaz, R.; Santiago-Cruz, J.A.; Zúñiga, G.; Rivera-Orduña, F.N. Degradation capacities of bacteria and yeasts isolated from the gut of Dendroctonus rhizophagus (Curculionidae: Scolytinae). Folia Microbiol. 2017, 62, 1-9. [CrossRef] [PubMed]

40. Morales-Jiménez, J.; de León, A.V.P.; García-Domínguez, A.; Martínez-Romero, E.; Zúñiga, G.; Hernández-Rodríguez, C. Nitrogen-fixing and uricolytic bacteria associated with the gut of Dendroctonus rhizophagus and Dendroctonus valens (Curculionidae: Scolytinae). Microb. Ecol. 2013, 66, 200-210. [CrossRef] [PubMed]

41. Winder, R.S.; Macey, D.E.; Cortese, J. Dominant bacteria associated with broods of mountain pine beetle, Dendroctonus ponderosae (Coleoptera: Curculionidae, Scolytinae). J. Entomol. Soc. Br. Columbia 2010, 107, 43-56.

42. $\mathrm{Hu}, \mathrm{X} . ; \mathrm{Yu}, \mathrm{J} . ;$ Wang, C.; Chen, H. Cellulolytic bacteria associated with the gut of Dendroctonus armandi larvae (Coleoptera: Curculionidae: Scolytinae). Forests 2014, 5, 455-465. [CrossRef]

43. Xu, L.; Lou, Q.; Cheng, C.; Lu, M.; Sun, J. Gut-associated bacteria of Dendroctonus valens and their involvement in verbenone production. Microb. Ecol. 2015, 70, 1012-1023. [CrossRef]

44. Harrington, T.C. Ecology and evolution of mycophagous bark beetles and their fungal partners. In Insect-Fungal Associations. Ecology and Evolution; Oxford University Press: New York, NY, USA, 2005; pp. 257-291.

45. Yilmax, H.; Sezen, K.; Kati, H.; Demirba ğ, Z. The first study on the bacterial flora of the European spruce bark beetle, Dendroctonus micans (Coleoptera: Scolytidae). Biologia 2006, 61, 679-686. [CrossRef]

46. Cardoza, Y.J.; Vasanthakumar, A.; Suazo, A.; Raffa, K.F. Survey and phylogenetic analysis of culturable microbes in the oral secretions of three bark beetle species. Entomol. Exp. Appl. 2009, 131, 138-147. [CrossRef]

47. Kati, A.; Kati, H. Isolation and identification of bacteria from Xylosandrus germanus (Blandford) (Coleoptera: Curculionidae). Afr. J. Microbiol. Res. 2013, 7, 5288-5289.

48. Adams, A.S.; Boone, C.K.; Bohlmann, J.; Raffa, K.F. Responses of bark beetle-associated bacteria to host monoterpenes and their relationship to insect life histories. J. Chem. Ecol. 2011, 37, 808-817. [CrossRef]

49. Menéndez, E.; Ramírez-Bahena, M.H.; Fabryová, A.; Igual, J.M.; Benada, O.; Mateos, P.F.; Peix, A.; Kolarik, M.; García-Fraile, P. Pseudomonas coleopterorum sp. nov.; a cellulase-producing bacterium isolated from the bark beetle Hylesinus fraxini. Int. J. Syst. Evol. Microbiol. 2015, 65, 2852-2858. [CrossRef]

50. Adams, A.S.; Currie, C.R.; Cardoza, Y.; Klepzig, K.D.; Raffa, K.F. Effects of symbiotic bacteria and tree chemistry on the growth and reproduction of bark beetle fungal symbionts. Can. J. For. Res. 2009, 39, 1133-1147. [CrossRef]

51. Canganella, F.; Paparatti, B.; Natali, V. Microbial species isolated from the bark beetle Anisandrus dispar F. Microbiol. Res. 1994, 149, 123-128. [CrossRef]

52. Wang, S.; Zhou, F.; Wang, B.; Xu, D.; Cao, Q.; Lu, M.; Sun, J. Volatiles produced by bacteria alleviate antagonistic effects of one associated fungus on Dendroctonus valens larvae. Sci. China Life Sci. 2017, 60, 924-926. [CrossRef] 
53. Zhou, F.; Xu, L.; Wang, S.; Wang, B.; Lou, Q.; Lu, M.; Sun, J. Bacterial volatile ammonia regulates the consumption sequence of D-pinitol and D-glucose in a fungus associated with an invasive bark beetle. ISME J. 2017, 11, 2809-2820. [CrossRef]

54. Therrien, J.; Mason, C.J.; Cale, J.A.; Adams, A.; Aukema, B.H.; Currie, C.R.; Raffa, K.F.; Erbilgin, N. Bacteria influence mountain pine beetle brood development through interactions with symbiotic and antagonistic fungi: Implications for climate-driven host range expansion. Oecologia 2015, 179, 467-485. [CrossRef]

55. Delalibera, I.; Vasanthakumar, A.; Klepzig, K.D.; Raffa, K.F. Composition of the bacterial community in the gut of the pine engraver, Ips pini (Say)(Coleoptera) colonizing red pine. Symbiosis 2007, 43, 97-104.

56. Ceja-Navarro, J.A.; Vega, F.E.; Karaoz, U.; Hao, Z.; Jenkins, S.; Lim, H.C.; Kosina, P.; Infante, F.; Northen, T.R.; Brodie, E.L. Gut microbiota mediate caffeine detoxification in the primary insect pest of coffee. Nat. Commun. 2015, 6, 7618. [CrossRef]

57. Chakraborty, A.; Ashraf, M.Z.; Modlinger, R.; Synek, J.; Schlyter, F.; Roy, A. Unravelling the gut bacteriome of Ips (Coleoptera: Curculionidae: Scolytinae): Identifying core bacterial assemblage and their ecological relevance. Sci. Rep. 2020, 10, 18572. [CrossRef]

58. Vasanthakumar, A.; Delalibera, I., Jr.; Handelsman, J.; Klepzig, K.D.; Schloss, P.D.; Raffa, K.F. Characterization of gut-associated bacteria in larvae and adults of the southern pine beetle, Dendroctonus frontalis Zimmermann. Environ. Entomol. 2006, 35, 1710-1717. [CrossRef]

59. Dohet, L.; Grégoire, J.C.; Berasategui, A.; Kaltenpoth, M.; Biedermann, P.H. Bacterial and fungal symbionts of parasitic Dendroctonus bark beetles. FEMS Microbiol. Ecol. 2016, 92, fiw129. [CrossRef] [PubMed]

60. Sevim, A.; Gökçe, C.; Erbaş, Z.; Özkan, F. Bacteria from Ips sexdentatus (Coleoptera: Curculionidae) and their biocontrol potential. J. Basic Microbiol. 2012, 52, 695-704. [CrossRef]

61. Sezen, K.; Kati, H.; Nalcacioĝlu, R.; Muratoĝlu, H.; Demirbaĝ, Z. Identification and pathogenicity of bacteria from European shot-hole borer, Xyleborus dispar Fabricius (Coleoptera: Scolytidae). Ann. Microbiol. 2008, 58, 173-179. [CrossRef]

62. Peral-Aranega, E.; Saati-Santamaría, Z.; Kolařik, M.; Rivas, R.; García-Fraile, P. Bacteria Belonging to Pseudomonas typographi sp. nov. from the Bark Beetle Ips typographus Have Genomic Potential to Aid in the Host Ecology. Insects 2020, 11, 593. [CrossRef] [PubMed]

63. Quince, C.; Walker, A.W.; Simpson, J.T.; Loman, N.J.; Segata, N. Shotgun metagenomics, from sampling to analysis. Nat. Biotechnol. 2017, 35, 833-844. [CrossRef] [PubMed]

64. López-Mondéjar, R.; Kostovčík, M.; Lladó, S.; Carro, L.; García-Fraile, P. Exploring the plant microbiome through multi-omics approaches. In Probiotics in Agroecosystem; Springer: Singapore, 2017; pp. 233-268.

65. Poveda, J.; Jiménez-Gómez, A.; Saati-Santamaría, Z.; Usategui-Martín, R.; Rivas, R.; García-Fraile, P. Mealworm frass as a potential biofertilizer and abiotic stress tolerance-inductor in plants. Appl. Soil Ecol. 2019, 142, 110-122. [CrossRef]

66. Douglas, G.M.; Beiko, R.G.; Langille, M.G. Predicting the functional potential of the microbiome from marker genes using PICRUSt. In Microbiome Analysis; Humana Press: New York, NY, USA, 2018; pp. 169-177.

67. Winand, R.; Bogaerts, B.; Hoffman, S.; Lefevre, L.; Delvoye, M.; Van Braekel, J.; Fu, Q.; Roosens, N.H.; De Keersmaecker, S.C.; Vanneste, K. Targeting the 16s rRNA gene for bacterial identification in complex mixed samples: Comparative evaluation of second (illumina) and third (oxford nanopore technologies) generation sequencing technologies. Int. J. Mol. Sci. 2020, 21, 298. [CrossRef]

68. Jiménez-Gómez, A.; Saati-Santamaría, Z.; Kostovcik, M.; Rivas, R.; Velázquez, E.; Mateos, P.F.; Menéndez, E.; García-Fraile, P. Selection of the Root Endophyte Pseudomonas brassicacearum CDVBN10 as Plant Growth Promoter for Brassica napus L. Crops. Agronomy 2020, 10, 1788. [CrossRef]

69. Sauvard, D. General biology of bark beetles. In Bark and Wood Boring Insects in Living Trees in Europe, a Synthesis; Springer: Dordrecht, The Netherlands, 2007; pp. 63-88.

70. Vega, F.E.; Hofstetter, R.W. (Eds.) Bark Beetles: Biology and Ecology of Native and Invasive Species; Academic Press: Cambridge, MA, USA, 2014.

71. Hofstetter, R.W.; Dinkins-Bookwalter, J.; Davis, T.S.; Klepzig, K.D. Symbiotic associations of bark beetles. In Bark Beetles; Academic Press: Cambridge, MA, USA, 2015; pp. 209-245.

72. Saha, B.C. Hemicellulose bioconversion. J. Ind. Microbiol. 2003, 30, 279-291. [CrossRef]

73. Zeeman, S.C.; Kossmann, J.; Smith, A.M. Starch: Its metabolism, evolution, and biotechnological modification in plants. Annu. Rev. Plant Biol. 2010, 61, 209-234. [CrossRef]

74. Carro, L.; Menéndez, E. Knock, knock-let the bacteria. In Molecular Aspects of Plant Beneficial Microbes in Agriculture; Academic Press: Cambridge, MA, USA, 2020; pp. 169-178.

75. Deryło, M.; Skorupska, A. Enhancement of symbiotic nitrogen fixation by vitamin-secreting fluorescent Pseudomonas. Plant Soil 1993, 154, 211-217. [CrossRef]

76. Marek-Kozaczuk, M.; Skorupska, A. Production of B-group vitamins by plant growth-promoting Pseudomonas fluorescens strain 267 and the importance of vitamins in the colonization and nodulation of red clover. Biol. Fertil. Soils 2001, 33, 146-151. [CrossRef]

77. Martens, J.H.; Barg, H.; Warren, M.A.; Jahn, D. Microbial production of vitamin B 12. Appl. Microbiol. Biotechnol. 2002, 58, 275-285. [CrossRef] [PubMed]

78. Riaz, M.; Ansari, Z.A.; Iqbal, F.; Akram, M. Microbial production of vitamin B12 by methanol utilizing strain of Pseudomonas specie. Pak. Biochem. Mol. Biol. 2007, 40, 5-10. 
79. Xia, W.; Chen, W.; Peng, W.F.; Li, K.T. Industrial vitamin B 12 production by Pseudomonas denitrificans using maltose syrup and corn steep liquor as the cost-effective fermentation substrates. Bioprocess Biosyst. Eng. 2015, 38, 1065-1073. [CrossRef]

80. Franceschi, V.R.; Krokene, P.; Christiansen, E.; Krekling, T. Anatomical and chemical defenses of conifer bark against bark beetles and other pests. New Phytol. 2005, 167, 353-376. [CrossRef]

81. Blomquist, G.J.; Figueroa-Teran, R.; Aw, M.; Song, M.; Gorzalski, A.; Abbott, N.L.; Chang, E.; Tittiger, C. Pheromone production in bark beetles. Insect Biochem. Mol. Biol. 2010, 40, 699-712. [CrossRef]

82. Xu, L.T.; Lu, M.; Sun, J.H. Invasive bark beetle-associated microbes degrade a host defensive monoterpene. Insect Sci. 2016, 23, 183-190. [CrossRef]

83. Martin, V.J.; Yu, Z.; Mohn, W.W. Recent advances in understanding resin acid biodegradation: Microbial diversity and metabolism. Arch. Microbiol. 1999, 172, 131-138. [CrossRef] [PubMed]

84. Kolařík, M.; Kostovčík, M.; Pažoutová, S. Host range and diversity of the genus Geosmithia (Ascomycota: Hypocreales) living in association with bark beetles in the Mediterranean area. Mycol. Res. 2007, 111, 1298-1310. [CrossRef] [PubMed]

85. Kolařík, M.; Kubátová, A.; Hulcr, J.; Pažoutová, S. Geosmithia fungi are highly diverse and consistent bark beetle associates: Evidence from their community structure in temperate Europe. Microb. Ecol. 2008, 55, 65-80. [CrossRef] [PubMed]

86. González-Dominici, L.I.; Saati-Santamaría, Z.; García-Fraile, P. Genome Analysis and Genomic Comparison of the Novel Species Arthrobacter ipsi Reveal Its Potential Protective Role in Its Bark Beetle Host. Microb. Ecol. 2020, 1-12. [CrossRef]

87. Lee, J.H.; Ma, K.C.; Ko, S.J.; Kang, B.R.; Kim, I.S.; Kim, Y.C. Nematicidal activity of a nonpathogenic biocontrol bacterium, Pseudomonas chlororaphis O6. Curr. Microbiol. 2011, 62, 746-751. [CrossRef]

88. Popa, V.; Déziel, E.; Lavallée, R.; Bauce, E.; Guertin, C. The complex symbiotic relationships of bark beetles with microorganisms: A potential practical approach for biological control in forestry. Pest Manag. Sci. 2012, 68, 963-975. [CrossRef]

89. Vodovar, N.; Vinals, M.; Liehl, P.; Basset, A.; Degrouard, J.; Spellman, P.; Boccard, F.; Lemaitre, B. Drosophila host defense after oral infection by an entomopathogenic Pseudomonas species. Proc. Natl. Acad. Sci. USA 2005, 102, 11414-11419. [CrossRef]

90. Otsu, Y.; Matsuda, Y.; Mori, H.; Ueki, H.; Nakajima, T.; Fujiwara, K.; Matsumoto, M.; Azuma, N.; Kakutani, K.; Nonomura, T.; et al. Stable phylloplane colonization by entomopathogenic bacterium Pseudomonas fluorescens KPM-018P and biological control of phytophagous ladybird beetles Epilachna vigintioctopunctata (Coleoptera: Coccinellidae). Biocontrol Sci. Technol. 2004, 14, 427-439. [CrossRef] 